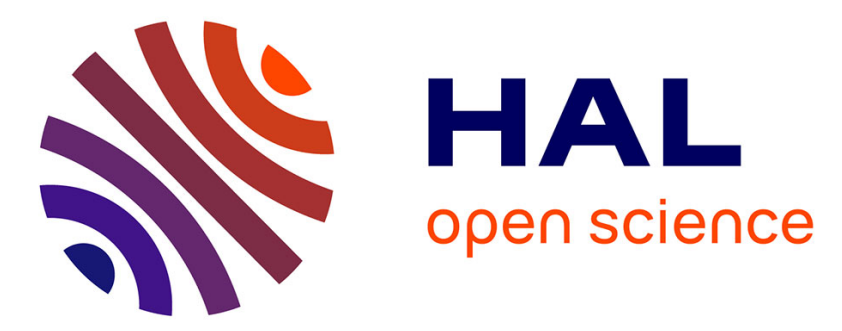

\title{
Plasmablastic crisis of Philadelphia chromosome-positive chronic myeloid leukemia
}

Kalliopi N. Manola, Despina Pantelidou, Maria Papaioannou

\section{To cite this version:}

Kalliopi N. Manola, Despina Pantelidou, Maria Papaioannou. Plasmablastic crisis of Philadelphia chromosome-positive chronic myeloid leukemia. Annals of Hematology, 2009, 89 (6), pp.641-642. 10.1007/s00277-009-0852-1 . hal-00486566

\section{HAL Id: hal-00486566 https://hal.science/hal-00486566}

Submitted on 26 May 2010

HAL is a multi-disciplinary open access archive for the deposit and dissemination of scientific research documents, whether they are published or not. The documents may come from teaching and research institutions in France or abroad, or from public or private research centers.
L'archive ouverte pluridisciplinaire HAL, est destinée au dépôt et à la diffusion de documents scientifiques de niveau recherche, publiés ou non, émanant des établissements d'enseignement et de recherche français ou étrangers, des laboratoires publics ou privés. 


\section{Editorial Manager(tm) for Annals of Hematology}

Manuscript Draft

Manuscript Number: AOHE-D-09-00277R1

Title: Plasmablastic crisis of Philadelphia chromosome positive Chronic Myeloid Leukemia

Article Type: Letter to the Editor

Keywords: CML; plasmablastic crisis; Philadelphia chromosome

Corresponding Author: Dr KALLIOPI MANOLA, Ph.D

Corresponding Author's Institution: NCSR "DEMOKRITOS"

First Author: Kalliopi Manola

Order of Authors: Kalliopi Manola; DESPINA PANTELIDOU; MARIA PAPAIOANNOU

Abstract: We report for the first time a rapidly fatal case of a Plasma Cell Leukemia crisis in a young patient with Ph chromosome positive CML. The patient, a 43-year-old male suffered from non diagnosed CML and presented at the time of blast crisis, which turned to be a plasmablastic leukemia. This hypothesis relies on the cytogenetic and immunophenotypic analysis of the leukemic cells. Two related clones were detected. The first clone was characterized only by $\mathrm{t}(9 ; 22)(\mathrm{q} 34 ; \mathrm{q} 11.2)$. The evolutionary clone showed severe hypodiploidy, including monosomy 13 and chromosome aberrations different from that of the blast crisis of CML, in addition to $t(9 ; 22)(q 34 ; q 11.2)$. Severe hypodiploid karyotype and monosomy 13 are common cytogenetic features of plasma cell leukemia. Positivity for CD38 and cytoplasmic kappa light chain revealed by immunophenotypic analysis of the leukemic cells, confirmed the plasmacytic origin of blasts. Therefore, the most likely diagnosis of our patient is that of Plasmablastic crisis of Philadelphia chromosome positive CML.

Response to Reviewers: Dear Sirs,

The manuscript was revised according to the Reviewer's comments as follows:

1) "The pictures relating to karyotypes should be deleted, the information is already in the text ".

- The pictures relating to karyotypes were deleted.

2) "Instead, a clear peripheral blood microphotograph (600-1000x) should document the presence of plasmablastic-type cells".

- A clear peripheral blood microphotograph (600x) was added to document the presence of plasmablastic-type cells.

3) "The immunophenotype study should report in detail the antisera used with respective percentages of positivity; this is especially important for CD45, CD20, CD56, CD30 and cytoplasmic/surface IgG and IgA (not reported in text)".

- The immunophenotype study is now reported in detail [CD45+ (79\%), CD38+(77\%), CD34+ (56\%), surface $\kappa(-)$, surface $\lambda(-)$, cytoplasmic $\kappa+(90 \%)$, cytoplasmic $\lambda(-)$, CD20 $(-)]$.

4) "Was kidney failure related to any degree of hypercalcemia or proteinuria? Were serum and urine free light chains quantified?"

- Neither hypercalcemia nor proteinuria was observed. Serum and urine free light chains were not quantified as the assay was not available.

Thank you very much for your suggestions. 
I am looking forward to hearing from you soon.

Yours Sincerely,

Kalliopi N. Manola

Associate Researcher in the laboratory of Cytogenetics

NCSR "Demokritos"

Athens, Greece.

E-mail: pmanola@ipta.demokritos.gr 
To: Tiziano Barbui Associate Editor

Annals of Hematology

October 6, 2009

Dear Dr Tiziano Barbui,

Please accept the revised manuscript, entitled "Plasmablastic crisis of Philadelphia chromosome positive Chronic Myeloid Leukemia" by K.N. Manola et al., for consideration for publication as Letter in Annals of Hematology, containing the corrections according to the reviewer's recommendations.

The manuscript was revised according to the Reviewer's comments as follows:

1) "The pictures relating to karyotypes should be deleted, the information is already in the text".

- The pictures relating to karyotypes were deleted.

2) "Instead, a clear peripheral blood microphotograph (600-1000x) should document the presence of plasmablastic-type cells".

- A clear peripheral blood microphotograph (600x) was added to document the presence of plasmablastic-type cells.

3) "The immunophenotype study should report in detail the antisera used with respective percentages of positivity; this is especially important for CD45, CD20, CD56, CD30 and cytoplasmic/surface IgG and IgA (not reported in text)".

- The immunophenotype study is now reported in detail [CD45+ (79\%), CD38+(77\%), CD34+ (56\%), surface $\mathrm{k}(-)$, surface $\lambda(-)$, cytoplasmic $\mathrm{k}+(90 \%)$, cytoplasmic $\lambda(-)$, CD20 (-)].

4) "Was kidney failure related to any degree of hypercalcemia or proteinuria? Were serum and urine free light chains quantified?'

- Neither hypercalcemia nor proteinuria was observed. Serum and urine free light chains were not quantified as the assay was not available.

Thank you very much for your suggestions.

I am looking forward to hearing from you soon.

Yours Sincerely,

Kalliopi N. Manola

Associate Researcher in the laboratory of Cytogenetics

NCSR "Demokritos"

Athens, Greece.

E-mail:pmanola@ipta.demokritos.gr 


\section{Plasmablastic crisis of Philadelphia chromosome positive Chronic Myeloid}

\section{Leukemia}

The cytogenetic hallmark of Chronic Myeloid Leukemia (CML) is the Philadelphia chromosome $(\mathrm{Ph})$, the consequence of the reciprocal translocation $\mathrm{t}(9 ; 22)(\mathrm{q} 34 ; \mathrm{q} 11.2)$ that results in the BCR-ABL1 fusion gene, located in the Ph chromosome. ${ }^{1}$ The natural history of untreated CML is an initial indolent chronic phase which is followed by a blast phase either suddenly or through an accelerated phase. Blast crisis may be diagnosed when blast cells are $\geq 20 \%$ of the peripheral blood WBC or the nucleated cells of the bone marrow or when there is an extramedullary blast proliferation. ${ }^{1,2}$ In approximately $70 \%$ of cases the blast lineage is myeloid while in $20-30 \%$ of cases the blasts are lymphoblasts. ${ }^{1,2}$ Progression is usually associated with clonal evolution, and at the time of transformation to blast crisis, $80 \%$ of patients demonstrate cytogenetic changes in addition to the $\mathrm{Ph}$ chromosome such as an extra Ph chromosome, $+8, \mathrm{i}(17 \mathrm{q})+19, \mathrm{t}(3 ; 21)(\mathrm{q} 26 ; \mathrm{q} 22)$, and very rarely $\mathrm{t}(7 ; 11)(\mathrm{p} 15 ; \mathrm{p} 15){ }^{3}$ Plasma Cell Leukemia (PCL) is an aggressive and rare hematological malignancy which is characterized by circulating plasma cells $>2 \times 10^{9} / 1$ in peripheral blood or by a plasmatocytosis $>20 \%$ of blood leukocytes and confers a poor prognosis. It originates as a primary disease or as a secondary leukemic transformation of multiple myeloma. ${ }^{4}$ The most frequent features at diagnosis are asthenia, severe anemia, thrombocytopenia, splenomegaly or hepatomegaly while CD38 and CD138 antigens are excellent plasma cell markers. ${ }^{5,6}$ In the majority of the cases karyotypes are complex and hypodiploid or pseudodiploid. Common chromosome abnormalities are $14 \mathrm{q} 32$ translocations such as $\mathrm{t}(11 ; 14)(\mathrm{q} 13 ; \mathrm{q} 32), \mathrm{t}(4 ; 14)(\mathrm{p} 16.3 ; \mathrm{q} 32), \mathrm{t}(14 ; 16)(\mathrm{q} 32 ; \mathrm{q} 23)$, deletions of the chromosomal regions $17 \mathrm{p} 13,13 \mathrm{q}$, and $1 \mathrm{p} 21$, monosomies of 
chromosomes 13 and $\mathrm{X}$ (in women), trisomy 18, amplification of 1q21, and MYC rearrangements. $^{4-7}$

Here, we report for the first time a rapidly fatal case of a Plasma Cell Leukemia crisis in a young patient with $\mathrm{Ph}$ chromosome positive $\mathrm{CML}$.

The patient, a 43-year-old male with a 2-month history of persistent fatigue, weakness and loss of weight was admitted to our department. On physical examination spleen was remarkably enlarged and routine complete blood count revealed leukocytosis with a WBC of $22 \times 10^{9} / 1$, anemia with a $\mathrm{Hb}$ of $7 \mathrm{gr} / \mathrm{dl}$, and thrombocytopenia with platelet count (PLT) of 30x10 $/ 1$. Neither hypercalcemia nor proteinuria was observed. Blood smear showed $90 \%$ blasts with the appearance of plasma blasts (Figure 1). Immunophenotyping of blast cells by flow cytometry showed CD45+ (79\%), CD38+(77\%), CD34+ (56\%), surface $\kappa(-)$, surface $\lambda(-)$, cytoplasmic $\kappa+(90 \%)$, cytoplasmic $\lambda(-)$, and CD20(-). The cytogenetic analysis of G-banded chromosomes in peripheral blood cells revealed two evolutionary clones, which were positive for $\mathrm{Ph}$ chromosome. The karyotype was described as: 46,XY,t(9;22)(q34;q11.2)[4]/

$32, X Y,-2,-3,-4,-5, t(9 ; 22)(q 34 ; q 11.2),-10,-11,-12,-13,-15,-16,-17,-18,-20,-22[16)]$.

Unfortunately, the patient developed acute renal failure on the second day after admission and died two days later.

$\mathrm{Ph}$ chromosome and/or BCR-ABL1 fusion gene which are detected in $90-95 \%$ of cases of CML is used as a major criterion for diagnosis of CML. ${ }^{1,2} \mathrm{Ph}$ chromosome, marked splenic enlargement, thrombocytopenia, and the high percentage of blasts are compatible with the diagnosis of blast crisis of CML. It seems possible that our patient suffered from non diagnosed CML and presented at the time of blast crisis, which turned to be a plasmablastic leukemia. This hypothesis relies on the cytogenetic and immunophenotypic analysis of the leukemic cells. Two related clones were 
detected in our patient. The first clone was characterized only by $\mathrm{t}(9 ; 22)(\mathrm{q} 34 ; \mathrm{q} 11.2)$, indicating that $\mathrm{Ph}$ chromosome was the primary aberration, possibly created in the chronic phase of CML. The evolutionary clone showed severe hypodiploidy, including monosomy 13 and chromosome aberrations different from that of the blast crisis of CML, in addition to $\mathrm{t}(9 ; 22)(\mathrm{q} 34 ; \mathrm{q} 11.2)$. Severe hypodiploid karyotype and monosomy 13 are common cytogenetic features of plasma cell leukemia. Positivity for CD38 and cytoplasmic kappa light chain revealed by immunophenotypic analysis of the leukemic cells, confirmed the plasmacytic origin of blasts. Therefore, the most likely diagnosis of our patient is that of Plasmablastic crisis of Philadelphia chromosome positive CML. To the best of our knowledge this case presents the first reported case of Plasmablastic crisis of $\mathrm{Ph}$ chromosome positive CML.

\author{
Kalliopi N Manola ${ }^{1 *}$, Despina Pantelidou ${ }^{2}$, Maria Papaioannou $^{2}$ \\ ${ }^{1}$ Laboratory of Cytogenetics, National Center for Scientific Research (NCSR) \\ “Demokritos”, 15310 Aghia Paraskevi, Athens, Greece \\ ${ }^{2} 1$ st Department of Internal Medicine, Hematology department, Medical School \\ AUTH, Thessaloniki, Greece \\ *E-mail: pmanola@ipta.demokritos.gr
}

\title{
References
}

1 Vardiman JW, Melo JV, Baccarani M, Thiele J. Chronic myelogenous leukaemia, BCR-ABL1 positive. Swerdlow SH, Campo E, Harris NL, Jaffe 
ES, Pileri SA, Stein H, Thiele J, et al. WHO Classification of Tumours of Haematopoietic and Lymphoid Tissues. 4th Edition 2008;32-7.

2 Vardiman JW, Thiele J, Arber DA, Brunning RD, Borowitz MJ, Porwit A, et al. The 2008 revision of the WHO classification of myeloid neoplasms and acute leukemia: rationale and important changes. Blood 2009; e-pub ahead of print 8 Apr 2009;doi:10.1182/blood-2009-03-209262.

3 Calabretta B, Perrotti D. The biology of CML blast crisis. Blood. 2004;103:4010-22.

4 Tiedemann RE, Gonzalez-Paz N, Kyle RA, Santana-Davila R, Price-Troska T, Van Wier SA, et al. Genetic aberrations and survival in plasma cell leukemia. Leukemia 2008;22:1044-52.

5 Costello R, Sainty D, Bouabdallah R, Fermand JP, Delmer A, Diviné M, et al. Primary plasma cell leukaemia: a report of 18 cases. Leuk Res. 2001;25:103-7.

6 García-Sanz R, Orfão A, González M, Tabernero MD, Bladé J, Moro MJ, et al. Primary plasma cell leukemia: clinical, immunophenotypic, DNA ploidy, and cytogenetic characteristics. Blood. 1999;93:1032-7.

7 Chang H, Qi X, Yeung J, Reece D, Xu W, Patterson B. Genetic aberrations including chromosome 1 abnormalities and clinical features of plasma cell leukemia. Leuk Res. 2009;33:259-62. 


\section{Legend to figure}

Figure 1. A peripheral blood microphotograph $(600 x)$ showing the presence of plasmablastic-type cells. 
Click here to download high resolution image

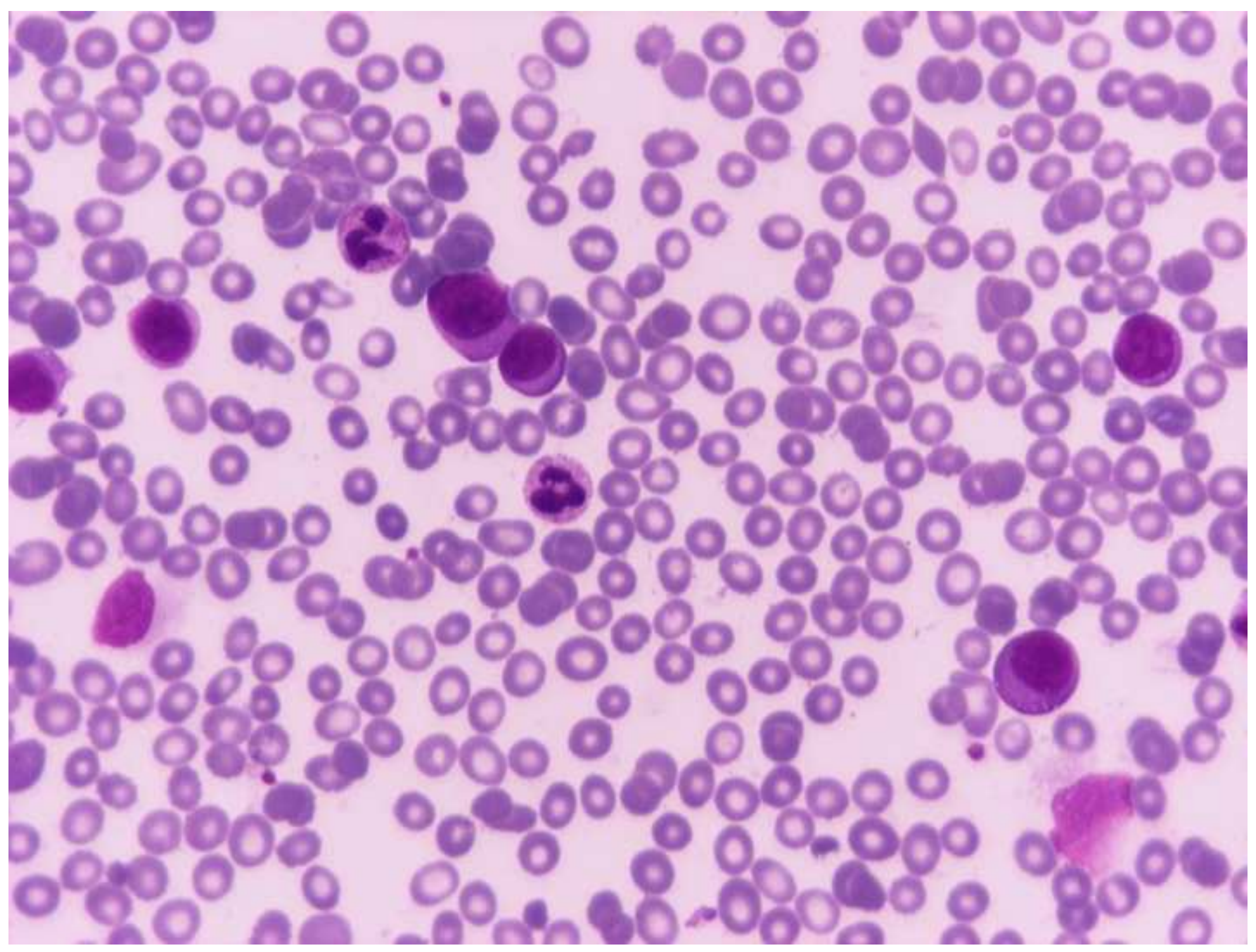

